\title{
PENGARUH PERSEPSI KOMPETENSI DASAR DOSEN TERHADAP MOTIVASI BELAJAR MAHASISWA
}

\section{(Studi pada Prodi Pendidikan Akuntansi Fakultas Keguruan Dan Ilmu Pendidikan Universitas Banten Jaya)}

\author{
Oleh: Sudaryono ${ }^{2)}$, Reni Febriani ${ }^{1)}$, Siti Rohmah ${ }^{3)}$ \\ Universitas Banten Jaya \\ Serang, Indonesia \\ renote28@gmail.com ${ }^{1)}$,rohmah_s60@yahoo.com ${ }^{3)}$
}

\begin{abstract}
This study aims determine the effect of Lecturer on the Motivation of Student Learning Result of Accounting Education Program Education Faculty at Banten Jaya University. This research uses quantitative approach method. The subjects of the study are students of Accounting Education Program Education Faculty at Banten Jaya University. In this research data technique used is questionnaire or questionnaire to 69 respondentsfrom 82 Accounting Education study program students.The method used in this research is descriptive research method, and practical analysis of data analysis, validity test, reliability test, normality test, homogeneity test, analysis, simple linear regression analysis, significance test (f test, $t$ test, coefficient of determination).From the results of data analysis that has been done to obtain the results that include the category "High Quality Basic Competence Lecturer" with a percentage of $78.63 \%$. Meanwhile, the motivation of student learning outcomes is categorized as "Highly Motivated" with a score of 3.98. The results obtained from the obtained motivation of 0.686 which means that Lecturer Basic Competence $(X)$ to Motivation Student Outcomes $(Y)$ is equal to $68.8 \%$ and the rest of $31.2 \%$ by other variables not examined. Thus it can be concluded that there is a significant influence between Basic Competence of Lecturers to Motivation Student Results this is because the value of $t$ count $>$ t table (7.711> 1.667) or significance $<0.05$ $(0.000<0.05)$ so that Ho is rejected.
\end{abstract}

Keywords: Basic Competence of Lecturers and Motivation of Learning Outcomes.

\section{PENDAHULUAN}

Pendidikan adalah satu sistem evaluasi untuk tiap-tiap individu untuk meraih pengetahuan serta pemahaman yang lebih tinggi tentang objek spesifik serta khusus. Pengetahuan yang didapat secara resmi itu menyebabkan pada tiaptiap individu dapat mempunyai pola pikir, tingkah laku serta akhlak yang sesuai dengan pendidikan yang diperolehnya (Kamus Besar Bahasa Indonesia). Menurut
Sardiman (2004) bahwa Pendidikan dan pengajaran adalah suatu proses yang sadar tujuan, dimana dapat diartikan sebagai suatu usaha untuk memberikan rumusan hasil yang diharapkan peserta didik setelah melaksanakan pengalaman belajar. Keberhasilan suatu proses pembelajaran akan dapat dilihat dari tercapainya tujuan akhir dari proses itu Proses belajar mengajar merupakan salah satu faktor dominan yang mempengaruhi kualitas 
belajar mahasiswa dan kualitas pendidikan yang dimotori oleh dosen. Dosen harus benar-benar profesional dalam menjalankan tugasnya sebagai pembaharu, sebagai contoh dalam masyarakat, sebagai motor penggerak dan pendorong, sebagai pembangkit minat peserta didik dalam belajar, untuk memajukan pendidikan bukan sebaliknya. (Maonde; 2011: 9). Berkaitan dengan minat peserta didik dalam belajar serta motivasinya yang berhubungan dengan kompetensi dasar dosen, seorang dosen diharapkan mampu menyampaikan mata kuliah dengan baik kepada mahasiswa, dan selalu memberikan informasi mengenai isu-isu terkini yang berkaitan dengan mata kuliah yang diampu. Dosen dalam hal ini berperan sebagai sumber pengetahuan utama dan pertama bagi mahasiswa di perguruan tinggi. Dosen yang berkompeten merupakan salah satu faktor yang dapat memotivasi mahasiswa untuk belajar. Sedangkan kompetensi dosen pada umumnya dilihat dari seberapa kemampuan dosen tersebut menguasai materi dalam menerapkan model pembelajaran yang tepat untuk materi yang akan diajarkan atau dipelajari oleh mahasiswa. Karena tujuan dari kegiatan belajar mengajar salah satunya adalah pencapaian seorang dosen dalam memberikan materi dengan baik dan dapat diterima oleh mahasiswa sehingga mahasiswa akan memberikan umpan balik serta hasil belajar yang baik. Diantara faktor-faktor yang dapat menurunkan motivasi belajar mahasiswa adalah kompetensi dosen, disiplin kerja, metoda mengajar, sarana belajar, iklim pembelajaran, lingkungan kampus, kepemimpinan dekan, beban studi, sistem organisasi fakultas, aturan-aturan yang diterapkan di fakultas, jadwal perkuliahan, dan tugas-tugas perkuliahan. (Tahrir,2013:757).

Kompetensi dosen dimungkinkan menjadi faktor yang dapat meningkatkan motivasi belajar mahasiswa karena dosen yang memiliki kompetensi dalam mengajar akan menguasai materi pelajarannya, memiliki metode pengajaran yang efektif, memiliki persiapan yang cukup ketika akan mengajar. Kompetensi dosen dapat dilihat dari pengalaman mengajar, latar belakang pendidikan formal, dan pengalaman mengikuti diklatdiklat peningkatan kualitas dosen. Usaha yang dilakukan oleh perguruan tinggi antara lain melakukan seleksi dan menaikkan standar pendidikan dosen. 
Berdasarkan UU No 14 Tahun 2005 tentang Guru dan Dosen dalam Pasal 45 menyatakan "Dosen wajib memiliki kualifikasi akademik, kompetensi, sertifikat pendidik, sehat jasmani dan rohani, dan memenuhi kualifikasi lain yang dipersyaratkan satuan pendidikan tinggi tempat bertugas, serta memiliki kemampuan untuk mewujudkan tujuan pendidikan nasional". Dan pada pasal 46 Ayat 2 yang berbunyi "Dosen memiliki kualifikasi akademik minimum lulusan program Magister (S2) untuk (Pengajar) Program Diploma atau Program Sarjana; dan lulusan Program Doktor untuk Program Pascasarjana". (Firdayanti 2012:3)

Berdasarkan hasil wawancara kepada beberapa mahasiswa Pendidikan Akuntasi mengenai kompetensi dosen di Prodi Pendidikan Akuntansi Fakultas Keguruan dan Ilmu Pendidikan Universitas Banten Jaya, diketahui bahwa proses pembelajaran masih belum efektif, seperti adanya dosen yang seringkali tidak menunaikan tugasnya dalam memberikan materi, seringkali datang terlambat, penyampaian materi oleh dosen kurang jelas dan sulit dipahami, metode mengajar yang digunakan tidak menarik, monoton dan kaku, pengelolaan kelas oleh dosen belum efektif dan kurangnya interaksi antara dosen dengan mahasiswa, sehingga hal ini menyebabkan terhambatnya proses pembelajaran.

Berkaitan dengan penerapan metode pembelajaran yang kurang menarik, monoton, dan kaku, salah satu contohnya yaitu dosen masih terpaku pada penggunaan metode ceramah, dimana beberapa dosen hanya menjelaskan materi secara lisan kepada mahasiswa sehingga proses pengajaran menjadi verbalisme saja, Selanjutnya komunikasi antara dosen dengan mahasiswa dan sebaliknya yang kurang diperhatikan, misalnya dosen yang berhalangan masuk kelas tanpa memberi tugas bahkan informasi kepada mahasiswa, sehingga proses kegiatan belajar mengajar tidak dilaksanakan, dan sebaliknya mahasiswa yang tidak mengikuti pelajaran tidak berkomunikasi dengan dosen terkait tugas dan apa yang harus dikerjakan, sehingga berpengaruh pada nilai.

Berdasarkan Indikasi ini memungkinkan adanya permasalahan mengenai kompetensi dosen. Hal ini mendorong dilakukannya penelitian mengenai kompetensi dosen Pendidikan akuntansi FKIP UNBAJA

Kompetensi adalah karakteristik mendasar dari individu yang berhubungan 
dengan ukuran atau referensi efektif atau tidaknya kinerja dalam suatu pekerjaan atau situasi tertentu (Grote dalam Anung Pramudyo 2010:3)

Dosen yang mempunyai kompetensi pada umumnya dilihat dari seberapa besar kemampuan dosen dalam menguasai materi dalam menerapkan model pembelajaran yang tepat untuk materi yang diajarkan atau pelajari. Menurut UU'No 14 tahun 2005 pasal 69 ayat 2 yang berbunyi "Pembinaan dan pengembangan profesi dosen sebagaimana pada ayat (1) meliputi kompetensi pedagogik, kompetensi kepribadian, kompetensi sosial, dan kompetensi profesional".

a. Kompetensi pedagogik meliputi pemahaman terhadap peserta didik, perancangan dan pelaksanaan pembelajaran, evaluasi belajar, dan pengembangan peserta didik untuk mengaktualisasikan berbagai potensi yang dimilikinya.

b. Kompetensi kepribadian merupakan kemampuan personal yang mencerminkan kepribadian yang mantap, stabil, arif, dan berwibawa serta dapat menjadi teladan peserta didik.

c. Kompetensi sosial merupakan kemampuan untuk berkomunikasi dan bergaul secara efektif dengan peserta didik, sesama pendidik, tenaga kependidikan, orang tua atau wali peserta didik, dan masyarakat sekitar.

d. Kompetensi professional merupakan penguasaan materi pembelajaran secara luas dan mendalam yang mencakup penguasaan materi kurikulum mata pelajaran di sekolah dan subtansi keilmuan yang menaungi materi serta penguasaan terhadap struktur dan metodologi keilmuannya.

Gordon dalam Mulyasa (2010:38) menjelaskan beberapa aspek yang terkandung dalam konsep kompetensi yaitu:

a. Pengetahuan (knowledge); yaitu kesadaran dalam bidang kognitif, misalnya seorang guru mengetahui cara melakukan identifikasi kebutuhan belajar, dan bagaimana melakukan pembelajaran terhadap peserta didik sesuai dengan kebutuhannya.

b. Pemahaman (understanding); yaitu kedalaman kognitif, dan afektif yang dimiliki oleh individu. Misalnya apabila seorang guru tersebut akan melaksanakan pembelajaran harus memiliki pemahaman yang cukup baik tentang karakteristik dan kondisi peserta didiknya, agar dapat 
melaksanakan pembelajaran secara efektif dan efisien.

c. Kemampuan (skill); adalah sesuatu yang dimiliki oleh individu untuk melakukan tugas atau pekerjaan yang dibebankan kepadanya. Misalnya kemampuan guru dalam memilih, dan membuat alat peraga sederhana untuk member kemudahan belajar kepada peserta didik.

d. Nilai (value); adalah suatu standar perilaku yang telah diyakini dan secara psikologis telah menyatu dalam diri seseorang. Misalnya pada standar perilaku guru dalam pembelajaran adalah menitik beratkan pada kejujuran, keterbukaan, demokratis, dan lain-lain.

e. Sikap (attitude); yaitu perasaan (senang-tidak senang, suka-tidak suka) atau reaksi terhadap suatu rangsangan yang datang dari luar. Misalnya apabila jika terjadi reaksi terhadap krisis ekonomi, maka akan ada perasaan terhadap kenaikan upah/gaji, dan sebagainya.

f. Minat (interest); adalah kecenderungan seseorang untuk melakukan sesuatu perbuatan. Misalnya minat untuk mempelajari atau melakukan sesuatu.

Pendidikan berbasis kompetensi adalah pendidikan yang menekankan pada kemampuan yang harus dimiliki oleh lulusan suatu jenjang pendidikan. Kompetensi lulusan suatu jenjang pendidikan, sesuai dengan tujuan pendidikan nasional, mencakup komponen pengetahuan, keterampilan, kecakapan, kemandirian, kreativitas, kesehatan, akhlak, ketakwaan, dan kewarganegaraan.

Menurut Wilson dalam Uno (2012:122) paradigma pendidikan berbasis kompetensi mencakup kurikulum, pedagogi, dan penilaian yang menekankan pada standar atau hasil, sedangkan kurikulum berisi bahan ajar yang diberikan kepada peserta didik melalui proses pembelajaran dilaksanakan dengan menggunakan pedagogi yang mencakup strategi atau metode mengajar. Tingkat keberhasilan belajar yang dicapai peserta didik dapat dilihat pada belajar, yang mencakup ujian, tugas-tugas, dan pengamatan.

Pendidikan berbasis kompetensi lebih menekankan kepada peningkatan kualitas pembelajaran dengan menekankan kepada student center, pembelajaran ini menekankan agar siswa berperan lebih aktif. Keaktifan belajar dipengaruhi oleh motivasi untuk belajar. 
Menurut Mc Donald, motivasi adalah perubahan energi dalam diri seseorang yang ditandai dengan munculnya feeling dan didahului dengan tanggapan terhadap adanya tujuan. Dari pengertian yang dikemukakan oleh Mc Donald ini, maka terdapat tiga elemen/ciri pokok dalam motivasi, yakni : motivasi mengawali terjadinya perubahan energi, ditandai dengan adanya feeling, dan dirangsang karena adanya tujuan (Pupuh Faturrohman dan M. Sobry Sutikno 2014:19).

Secara umum biasanya motivasi didefinisikan sebagai sesuatu yang memberi energi dan mengarahkan perilaku. tentu saja ini merupakan definisi umum, definisi yang dapat diaplikasikan untuk banyak faktor yang mempengaruhi perilaku. Kesediaan siswa untuk belajar adalah hasil dari banyak faktor. Mulai dari kepribadian mahasiswa dan kemampuan mahasiswa untuk menyelesaikan tugastugas sebagai pelajar.

Oemar Hamalik dalam Pupuh Faturrohman dan M. Sobry Sutikno 2014:19), menyatakan bahwa ada tiga fungsi motivasi :

a. Mendorong manusia untuk berbuat, jadi sebagai penggerak atau motor yang melepas energi. Dimana motivasi dalam hal ini merupakan langkah penggerak dari setiap kegiatan yang akan dikerjakan.

b. Menentukan arah perbuatan yakni kearah tujuan yang hendak dicapai. Dengan demikian motivasi dapat memberikan arah dan kegiatan yang harus dikerjakan sesuai dengan rumusan tujuannnya.

c. Menyeleksi perbuatan, yakni menentukan perbuatan-perbuatan yang harus dikerjakan yang serasi guna mencapai tujuan, dengan menyisihkan perbuatan-perbuatan yang tidak bermanfaat bagi tujuan tersebut.

Dari beberapa uraian diatas, Nampak jelas bahwa motivasi berfungsi sebagai pendorong, pengarah, dan sekaligus sebagai penggerak prilaku seseorang untuk mencapai suatu tujuan.

Berdasarkan latar belakang tersebut maka peneliti tertarik mengkaji lebih dalam tentang Pengaruh Persepsi Kompetensi Dasar Dosen Terhadap Motivasi Belajar Mahasiswa

\section{METODE PENELITIAN}

Penelitian dilakukan di Fakultas Keguruan dan Ilmu Pendidikan Prodi Akuntansi Universitas Banten Jaya (UNBAJA). 
Populasi merupakan gabungan dari elemen yang berbentuk peristiwa, hal atau orang yang memiliki karakteristik yang serupa yang menjadi pusat perhatian seorang peneliti karena itu dipandang sebagai semesta penelitian (Cooper dalam Sudaryono 2016:117) Populasi adalah wilayah generalisasi yang terdiri dari: objek atau subjek yang mempunyai kualitas dan karakteristik tertentu yang ditetapkan oleh peneliti untuk dipelajari kemudian ditarik kesimpulannya (Kurniawan dalam Sudaryono 2016:117). Jadi populasi bukan hanya orang, tetapi juga objek dan benda-benda alam yang lain. Populasi juga bukan sekedar jumlah yang ada pada objek atau subjek yang dipelajari, tetapi meliputi seluruh karakteristik atau sifat yang dimiliki oleh subjek atau objek itu. Jadi populasi dalam penelitian ini adalah seluruh Mahasiswa Prodi Pendidikan Akuntansi Fakultas Keguruan dan Ilmu Pendidikan Universitas Banten Jaya (UNBAJA).

Dalam penelitian ini peneliti menggunakan penelitian sampel karena subjek penelitiannya diambil >30 responden mahasiswa Prodi Akuntansi Fakultas Keguruan dan Ilmu PendidikanUniversitas Banten Jaya, dengan menggunakan metode penarikan sampel probabilitas. Dalam hal ini, setiap elemen populasi memiliki peluang atau probabilitas yang sama untuk dipilih sebagai sampel, penarikan sampel probabilitas berdasarkan metode pemilihan random atau acak (Sunyoto dalam Sudaryono 2016:121). Sampel penelitian ini dihitung dengan rumus slovin (Umar dalam Sudaryono 2016:141)

$$
n=\frac{N}{1+N e^{2}}
$$

Keterangan:

$\mathrm{n}$ : ukuran sampel

$\mathrm{N}$ : ukuran populasi

e : kelonggaran ketidaktelitian karena kesalahan pengambilan sampel yang dapat ditolerir

Berikut ini jumlah mahasiswa Prodi Akuntansi yang terdaftar sebagai mahasiswa aktif pada tahun 2015 sampai 2017, yang akan diambil sebagai sampel responden.

Tabel 1. Jumlah Mahasiswa

\begin{tabular}{ccc}
\hline No & $\begin{array}{c}\text { Tahun } \\
\text { Angkatan }\end{array}$ & $\begin{array}{c}\text { Jumlah } \\
\text { Mahasiswa }\end{array}$ \\
\hline 1 & 2015 & 15 \\
2 & 2016 & 44 \\
3 & 2017 & 23
\end{tabular}

Total 82

Sumber : Bagian Akademik FKIP UNBAJA 
jadi jumlah sampel yang akan diambil (n), dengan nilai kritis / batas kesalahan (e) $5 \%$ dari populasi (N) tersebut adalah:

$$
n=\frac{82}{1+82(0,05)^{2}}
$$

$\mathrm{n}=68,04$ atau sekitar 69 mahasiswa yang akan menjadi sampel

Batas toleransi kesalahan ini dinyatakan dengan persentase. Semakin kecil toleransi kesalahan, maka akan semakin akurat sampel yang mewakili populasi.

Menurut Sugiyono (2015) Variabel penelitian adalah suatu atribut atau sifat atau nilai dari orang atau objek yang mempunyai variasi antara satu dengan yang lainnya atau satu objek dengan objek lainnya.

Sedangkan secara teoritis variabel dapat didefiniskan sebagai atribut seseorang, atau objek yang mempunyai variasi antara satu dengan yang lainnya. Variabel juga dapat merupakan atribut dari bidang keilmuwan atau kegiatan tertentu (Sudjarwo \& Basrowi dalam Sudaryono 2016:45). Dalam penelitian ini peneliti menggunakan dua variabel yaitu :

a. Variabel independen sering disebut variabel stimulus, predictor, antecedent. Dalam bahasa Indonesia sering disebut sebagai variabel bebas. Variabel bebas merupakan variabel yang memengaruhi atau yang menjadi sebab perubahannya atau timbulnya variabel dependen (terikat). Variabel independent (bebas) adalah variabel yang menjelaskaan atau memengaruhi variabel yang lain. Dalam penelitian ini yang menjadi variabel independen adalah: Kompetensi Dasar Dosen (X).

b. Sugiyono (2015) mengartikan variabel dependen sebagai variabel yang sifatnya dipengaruhi oleh variable lain. Dalam penelitian ini yang menjadi variabel dependen adalah : Motivasi Belajar Mahasiswa (Y).

Teknik Pengumpulan Data

1. Angket

2. Wawancara

Keabsahan Data

1. Pengujian Validitas Kuesioner

2. Pengujian Reliabilitas Kuesioner

Teknik Analisis Data

1. Pemberian bobot nilai

2. Rekapitulasi data variable

3. Komponen variable

4. Analisis data

5. Uji validitas

6. Uji reabilitas

7. Uji normalitas

8. Uji homogenitas 
9. Analisis korelasi product moment

10. Analisis regresi linear sederhana

11. Uji signifikansi
a. Uji F
b. Uji t

12. Koefisien determinasi

13. Hipotesis statistic

\section{HASIL PENELITIAN DAN \\ PEMBAHASAN}

Setelah data-data yang penulis kumpulkan lengkap, maka selanjutnya penulis melakukan analisis kuantitatif atau yang sering disebut juga dengan analisis data statistik. Untuk mengetahui ada atau tidaknya Pengaruh Kompetensi Dasar Dosen (X) Terhadap Motivasi Belajar Mahasiswa Prodi Akuntansi Fakultas Keguruan dan Ilmu PendidikanUniversitas Banten Jaya (Y), maka datadata yang diperoleh dianalisis dengan menggunakan analisis Uji F.

Dari hasil jawaban pada kuesioner yang telah diisi oleh 69 responden dapat disimpulkan bahwa pernyataan dari setiap indikator menggambarkan bahwa terdapat pengaruh antara Kompetensi Dasar Dosen Terhadap Motivasi Belajar Mahasiswa Prodi Akuntansi Fakultas Keguruan dan Ilmu Pendidikan-Universitas Banten Jaya.

Perhitungan untuk mengetahui seberapa tinggi kompetensi dosen dalam memberikan pembelajaran kepada mahasiswa:

$$
p=\frac{5.426}{69} \times 100 \%
$$

$p=78,63 \%$

Perhitungan selanjutnya dilakukan untuk mengetahui seberapa tinggi motivasi belajar mahasiswa yang berhubungan dengan kompetensi dosen

$$
\begin{gathered}
x=\frac{5.426}{69}=78,63 \% \\
y=\frac{1.361}{69}=19,72
\end{gathered}
$$

Kemudian hasil dari $\mathrm{x} 1$ dan $\mathrm{y} 1$ yang sudah diketahui diaplikasikan kedalam rumus :

$$
\begin{aligned}
& \text { Hasil }=\frac{78.63}{19.72} \\
& \text { Hasil }=3.98
\end{aligned}
$$

\section{Uji Validitas}

Pengujian validitas menggunakan program aplikasi SPSS dengan metode Pearson Correlation, yaitu mengkorelasikan tiap item dengan skor total item kuesioner.

- Jika $r_{\text {hitung }}>r_{\text {tabel }}$, maka item pertanyaan dinyatakan valid

- jika $r_{\text {hitung }}<r_{\text {tabel}}$, maka item pertanyaan dinyatakan tidak valid.

nilai $r$ tabel dapat dilihat pada tabel statistik $r$ dengan $n=69$ atau $d f=n-2=67$ dan dengan siginifikansi 0,05 maka didapat $\mathrm{r}$ tabel $=0,236$ 
Tabel 2

Uji Validitas Kompetensi Dasar Dosen Hasil Uji Validitas Variabel X

\begin{tabular}{ccccc}
\hline Var & $\begin{array}{c}\text { Pern } \\
\text { yata } \\
\text { an }\end{array}$ & $\begin{array}{c}\mathrm{R} \\
\text { hitung }\end{array}$ & $\begin{array}{l}\text { rtabel }= \\
0,236 \alpha= \\
0,05 ; \mathrm{df}= \\
(\mathrm{N}-2)\end{array}$ & Ket \\
\hline & 1 & 0,760 & $>0,236$ & Valid \\
& 2 & 0,735 & $>0,236$ & Valid \\
& 3 & 0,779 & $>0,236$ & Valid \\
& 4 & 0,775 & $>0,236$ & Valid \\
& 5 & 0,801 & $>0,236$ & Valid \\
& 6 & 0,625 & $>0,236$ & Valid \\
& 7 & 0,657 & $>0,236$ & Valid \\
Komp & 8 & 0,568 & $>0,236$ & Valid \\
Densi & 9 & 0,786 & $>0,236$ & Valid \\
Dosar & 10 & 0,559 & $>0,236$ & Valid \\
nos) & 11 & 0,630 & $>0,236$ & Valid \\
& 12 & 0,753 & $>0,236$ & Valid \\
& 13 & 0,767 & $>0,236$ & Valid \\
& 14 & 0,687 & $>0,236$ & Valid \\
& 15 & 0,689 & $>0,236$ & Valid \\
& 16 & 0,743 & $>0,236$ & Valid \\
& 17 & 0,817 & $>0,236$ & Valid \\
& 18 & 0,692 & $>0,236$ & Valid \\
& 19 & 0,678 & $>0,236$ & Valid \\
& 20 & 0,690 & $>0,236$ & Valid \\
\hline
\end{tabular}

Sumber: Data yang diolah 2018
Tabel 3

Uji Validitas Motivasi Belajar Mahasiswa

\begin{tabular}{cccll}
\hline Var & $\begin{array}{c}\text { Per } \\
\text { nyat } \\
\text { aan }\end{array}$ & $\begin{array}{c}\mathrm{R} \\
\text { hitung }\end{array}$ & $\begin{array}{l}\text { rtabel }= \\
0,236 \alpha \\
=0,05 ; \\
\mathrm{df}= \\
(\mathrm{N}-2)\end{array}$ & Ket \\
\hline Moti & 1 & 0.624 & $>0,236$ & Valid \\
vasi & 2 & 0.684 & $>0,236$ & Valid \\
Bela & 3 & 0.507 & $>0,236$ & Valid \\
jar & 4 & 0.588 & $>0,236$ & Valid \\
(Y) & 5 & 0.661 & $>0,236$ & Valid \\
\hline
\end{tabular}

Sumber: Data yang diolah 2018

\section{Hasil Uji Validitas Variabel Y}

Dapat diketahui bahwa untuk variable $\mathrm{X}$ dan $\mathrm{Y}$ semua item pertanyaan nilai Pearson Correlation lebih dari $\mathrm{r}$ tabel 0,236. Jadi dapat disimpulkan bahwa itemitem kuesioner untuk variabel tersebut telah valid.

\section{Uji Reliabilitas}

Uji reliabilitas adalah ukuran mengenai konsistensi internal dari indikator sebuah konstruk yang menunjukan derajat sampai di mana masing-masing indikator itu mengindikasikan sebuah konstruk/faktor laten yang umum, (Ferdinad, 2014).

Metode pengujian reliabilitas yang digunakan pada penelitian ini adalah Cronbach's Alpha.

Menurut Agung AWS Waspodo et al. dalam Umar (2013:104) uji reliabilitas 
untuk alternatif jawaban lebih dari dua menggunakan uji cronbach's alpha,yang nilainya akan dibandingkan dengan nilai koefisien reliabilitas minimal yang dapat diterima. Reliabilitas kurang dari 0.6 adalah kurang baik, sedangkan 0.7 dapat diterima, dan lebih dari 0.8 adalah baik. Kriteria pengujiannya adalah sebagai berikut:

a. Jika nilai nilai cronbach's alpha> 0.6, maka instrumen penelitian reliabel.

b. Jika nilai cronbach's alpha $<0.6$, maka instrumen penelitian tidak reliabel.

Hasil uji reliabilitas dapat dilihat

Output reliabilitas (pada nilai Cronbach

Alpha). Dapat diketahui nilai Cronbach Alpha untuk variabel $\mathrm{X}$ dan $\mathrm{Y}$ di atas 0,600. Karena nilai diatas 0,600. Karena nilai diatas 0,600 jadi dapat disimpulkan bahwa alat ukur pada kuesioner telah reliabel.

\section{Uji Normalitas}

Uji normalitas dimakasudkan untuk mengetahui kenormalan distribusi data. Dalam penelitian ini uji normalitas didasarkan pada uji One Sample Kolmogrov Smirnov dengan bantuan program SPSS for Windows versi 21-

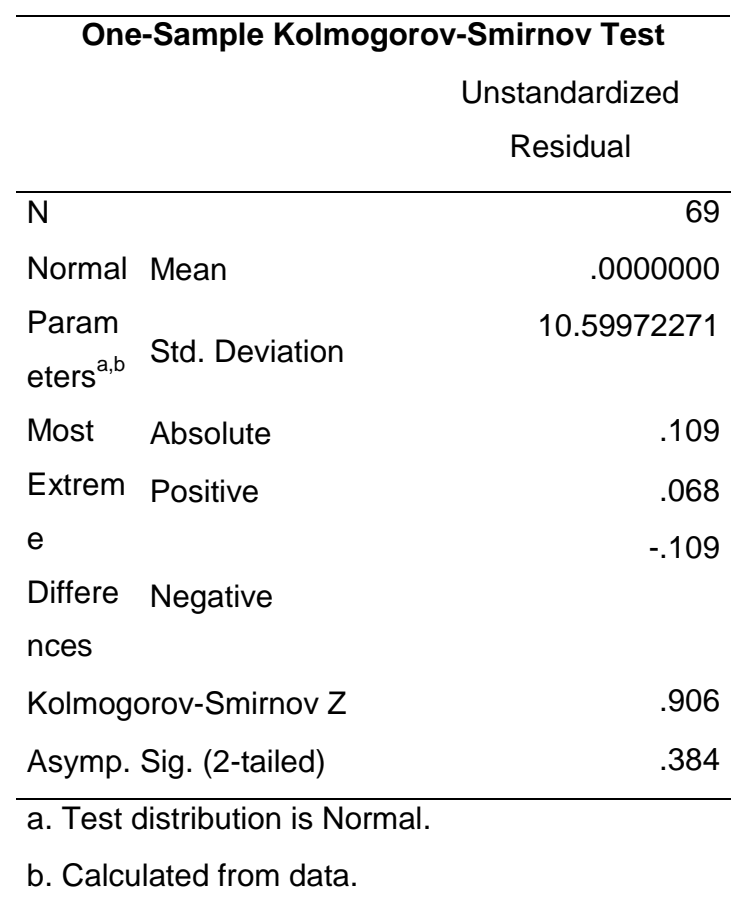

Berdasarkan output diatas, diketahui bahwa nilai signifikansi sebesar 0,384 lebih besar dari 0,05, sehingga dapat disimpulkan bahwa data yang telah di uji berdistribusi normal.

\section{Uji Homogenitas}

Uji homogenitas digunakan untuk mengetahui apakah sampel berasal dari populasi yang sama. Kesamaan asal sampel tersebut dibuktikan dengan adanya kesamaan variansi kelompok-kelompok yang membentuk sampel tersebut. Dalam penelitian ini ujihomogenitas dilakukan menggunakan ANOVA dengan bantuan program SPSS for Windows versi 21. 
Test of Homogeneity of Variances

Motivasi Belajar Mahasiswa

\begin{tabular}{|r|r|r|r|}
\hline $\begin{array}{l}\text { Levene } \\
\text { Statistic }\end{array}$ & \multicolumn{1}{|c|}{$\mathrm{df1}$} & \multicolumn{1}{c|}{$\mathrm{df2}$} & Sig. \\
\hline 1.878 & 14 & 36 & .064 \\
\hline
\end{tabular}

Berdasarkan output SPSS diatas diketahui bahwa nilai signifikansi variabel Motivasi Belajar Mahasiswa berdasarkan variabel Kompetensi Dasar Dosen $(X)=0,064>0,05$, artinya data variabel Motivasi Belajar Mahasiswa (Y) berdasarkan variabel Kompetensi Dasar Dosen $(\mathrm{X})$ mempunyai varian yang sama.

\section{Uji Hipotesis}

\section{Analisis Korelasi Product Moment :}

Untuk mengetahui pengaruh antara variabel Kompetensi Dasar Dosen dan Variabel Motivasi Belajar Mahasiswa, dari hasil pengolahan data maka dapat dilihat sebagai berikut:

\begin{tabular}{|c|c|c|c|}
\hline \multicolumn{4}{|c|}{$\begin{array}{lc}\text { Correlations } \\
\end{array}$} \\
\hline & & \multirow{3}{*}{$\begin{array}{c}\text { Kompetensi } \\
\text { Dasar } \\
\text { Dosen }(\mathrm{X})\end{array}$} & \multirow{4}{*}{$\begin{array}{c}\text { Motivasi } \\
\text { Belajar } \\
\text { Mahasisw } \\
\text { a (Y) }\end{array}$} \\
\hline & & & \\
\hline & & & \\
\hline & & & \\
\hline \multirow{4}{*}{$\begin{array}{l}\text { Kompetensi } \\
\text { Dasar Dosen } \\
\text { (X) }\end{array}$} & Pearson & 1 & $.686^{* *}$ \\
\hline & Correlation & & \\
\hline & Sig. (2-tailed) & & .000 \\
\hline & $\mathrm{N}$ & 69 & 69 \\
\hline \multirow{2}{*}{$\begin{array}{l}\text { Motivasi } \\
\text { Belajar }\end{array}$} & Pearson & $.686^{* *}$ & 1 \\
\hline & Correlation & & \\
\hline Mahasiswa & Sig. (2-tailed) & .000 & \\
\hline$(\mathrm{Y})$ & $\mathrm{N}$ & 69 & 69 \\
\hline $\begin{array}{l}* * \text {. Correlati } \\
\text { tailed). }\end{array}$ & is significant & the 0.01 leve & $1(2-$ \\
\hline
\end{tabular}

\section{Analisis Regresi Linear Sederhana}

Analisis regresi linear sederhana digunakan untuk mengetahui pengaruh variabel independen terhadap variabel dependen baik secara parsial (Uji t) maupun secara bersama-sama (Uji F). Persamaan regresi dan untuk mengetahui nilai peningkatan atau penurunan variabel $\mathrm{Y}$ atau perubahan variabel $\mathrm{X}$.

Bentuk umum persamaan regresi linear sederhana yaitu sebagai berikut:

$$
\mathrm{Y}=\mathrm{a}+\mathrm{bX}
$$

Hasil yang diperoleh setelah data diolah dengan bantuan program SPSS disajikan dalam tabel berikut ini: 


\begin{tabular}{|c|c|c|c|c|c|}
\hline \multicolumn{6}{|c|}{ Coefficients $^{a}$} \\
\hline \multirow[t]{3}{*}{ Model } & \multicolumn{2}{|c|}{$\begin{array}{l}\text { Unstandardized } \\
\text { Coefficients }\end{array}$} & \multirow{2}{*}{$\begin{array}{c}\text { Standa } \\
\text { rdized } \\
\text { Coeffic } \\
\text { ients }\end{array}$} & \multirow[t]{3}{*}{$\mathrm{t}$} & \multirow[t]{2}{*}{ Sig. } \\
\hline & & & & & \\
\hline & B & $\begin{array}{l}\text { Std. } \\
\text { Error }\end{array}$ & Beta & & \\
\hline (Constant) & 7.138 & 1.660 & & 4.300 & .000 \\
\hline Kompetensi & .160 & .021 & .686 & 7.711 & .000 \\
\hline \multicolumn{6}{|l|}{ Dasar } \\
\hline \multicolumn{6}{|l|}{ Dosen (X) } \\
\hline a. Dependen & Variable: & lotivasi E & Belajar M & hasiswe & \\
\hline
\end{tabular}

Persamaan regresinya sebagai berikut:

$Y=7.138+0,160 X$

\section{Uji t}

Uji $\mathrm{t}$ dalam regresi sederhana digunakan untuk mengetahui apakah model regresi variabel independen secara parsial berpengaruh signifikan terhadap variabel dependen.

Hipotesis:

- Ho : Tidak ada pengaruh X terhadap Y

- Ha : ada pengaruh $\mathrm{X}$ terhadap $\mathrm{Y}$

Kriteria pengambilan keputusan:

- Ho diterima bila $-\mathrm{t}_{\text {hitung }} \geq-\mathrm{t}_{\text {tabel }}$ atau $t_{\text {hitung }} \leq t_{\text {tabel }}($ tidak berpengaruh)

- Ho ditolah bila $-\mathrm{t}_{\text {hitung }}<-\mathrm{t}_{\text {tabel }}$ atau $t_{\text {hitung }}>t_{\text {tabel }}($ berpengaruh)

Catatan: Nilai t tabel dapat dilihat pada tabel $\mathrm{t}$ statistik pada $\mathrm{df}=\mathrm{n}-\mathrm{k}-1$ atau $69-1-1=67$ ( $\mathrm{k}$ adalah jumlah variabel independen). Dengan signifikansi 0,05, dan uji 2 sisi. Diperoleh hasil t tabel $0,236 /-0,236$.

\section{Koefisien Determinasi}

Koefisien determinasi adalah ukuran yang menunjukkan seberapa besar variabel $\mathrm{X}$ memberikan kontribusi terhadap varibel Y. Koefisien determinasi digunakan untuk mengetahui prosentase sumbangan pengaruh variabel independen secara serentak terhadap variabel dependen.

Penelitian ini menggunakan bantuan program aplikasi SPSS (Statistical Program for Social Science) for Windows Release versi 21. Dari penelitian yang telah dilakukan dengan menyebarkan kuesioner kepada 69 responden maka dapat diketahui seberapa besar Pengaruh Persepsi Kompetensi Dasar Dosen terhadap Motivasi Belajar Mahasiswa Prodi Pendidikan Akuntansi Fakultas Keguruan dan Ilmu PendidikanUniversitas Banten Jaya.

Dari hasil analisis data yang telah dilakukan dapat diketahui bahwa hasil penelitian ini menunjukkan adanya pengaruh yang signifikan antara variabel kompetensi dasar dosen terhadap motivasi belajar mahasiswa FKIP UNBAJA. Hal ini dibuktikan dari hasil perhitungan analisis 
data statistik yang telah dilakukan dan diperoleh hasil demikian.

Diketahui hasil dari prosentase kompetensi dasar dosen yang diambil berdasarkan dari jawaban rsponden sebesar $78.63 \%$ yang menunjukkan bahwa kualitas kompetensi dasar dosen termasuk kedalam kategori "Kualitas Kompetensi

\section{Dasar Dosen Tinggi".}

Hasil prosentase motivasi belajar mahasiswa yang diperoleh dari perhitungan diatas sebesar 3,98 dimana hasil ini menunjukkan bahwa motivasi belajar mahasiswa terhadap kompetensi dasar dosen Prodi Pendidikan Akuntansi FKIP UNBAJA termasuk kedalam kategori "Sangat Termotivasi".

Dari hasil output diatas, diperoleh harga koefisien korelasi sebesar 0,686 dengan nilai signifikansi yang dimiliki oleh Kompetensi Dasar Dosen sebesar 0,000. Berdasarkan data tersebut diatas maka dapat dilakukan pengujian hipotesis dengan membandingkan taraf signifikansi (p-value), dimana :

Jika Signifikansi>0,05, maka Ho diterima Jika Signifikansi < 0,05, maka Ho ditolak

Pada kasus ini terlihat bahwa koefisien korelasi adalah 0,686 dengan signifikansi 0,000. Karena signifikansi < 0,05 maka Ho ditolak berarti Ha diterima.
Artinya ada pengaruh yang signifikan antara Kompetensi Dasar Dosen terhadap Motivasi Belajar Mahasiswa Prodi Pendidikan Akuntansi FKIP UNBAJA

koefisien korelasi hasil analisis korelasi product moment Dengan taraf kepercayaan 5\% diperoleh harga $\mathrm{r}$ tabel 0,236 . Ternyata $r$ hitung lebih besar dari $r$ tabel $(0,686>0,236)$, sehingga Ho ditolak dan Ha diterima, yang artinya Kompetensi Dasar Dosen mempunyai pengaruh yang signifikan dengan Motivasi Belajar Mahasiswa. Berdasarkan hasil koefisien korelasi tersebut juga dapat dipahami bahwa korelasinya bersifat positif, artinya semakin tinggi tingkat kompetensi dasar dosen maka akan dibarengi dengan semakin tinggi pula motivasi belajar mahasiswa. Dengan memperhatikan harga koefisien korelasinya sebesar 0,686 berarti korelasinya bersifat kuat.

Dilihat dari hasil output pada analisis perhitungan uji $\mathrm{t}$ maka dapat disimpulkan bahwa variabel kompetensi dasar dosen berpengaruh terhadap motivasi belajar mahasiswa. Hal ini karena nilai $\mathrm{t}$ hitung $>\mathrm{t}$ tabel $(7,711>$ 1,667) atau signifikansi $<0,05(0,000<$ 0,05) sehingga Ho ditolak. Pengaruhnya positif karena nilai t hitung positif, artinya jika kompetensi dasar dosen meningkat 
maka motivasi belajar mahasiswa juga meningkat.

Dari hasil output yang diperoleh dari perhitungan koefisien determinasi menunjukkan bahwa variabel kompetensi dasar dosen memiliki sumbangan pengaruh terhadap motivasi belajar mahasiswa sebesar 0,470 atau $47 \%$ dan sisanya dipengaruhi faktor lain yang tidak diteliti.

Dengan demikian bahwa hasil penelitian ini menyatakan $\mathrm{Ha}$ yaitu "Terdapat Pengaruh Persepsi Kompetensi Dasar Dosen terhadap Motivasi Belajar Mahasiswa Prodi Pendidikan Akuntansi Fakultas Keguruan dan Ilmu PendidikanUniversitas Banten Jaya”.

\section{KESIMPULAN DAN SARAN}

Berdasarkan penelitian dan pembahasan, dapat disimpulkan bahwa:

1. Berdasarkan hasil dari perhitungan prosentase kompetensi dasar dosen diketahui $78,63 \%$ yang menunjukkan bahwa kompetensi dasar dosen prodi Pendidikan Akuntansi FKIP UNBAJA termasuk kedalam kategori "Kualitas Kompetensi Dasar DosenTinggi”.

2. Berdasar hasil perhitungan motivasi belajar mahasiswa diketahui 3,98 hasil ini menunjukkan bahwa motivasi belajar mahasiswa terhadap kompetensi dasar dosen kedalam kategori "Sangat Termotivasi".

3. Nilai t hitung sebesar 7,711 dan t tabel 1,667. Dimana hasil hipotesis statistik menerangkan bahwa Ho ditolak dan Ha diterima. Dengan demikian dapat disimpulkan bahwa ada pengaruh yang signifikan antaraKompetensi Dasar Dosen terhadap Motivasi Belajar Mahasiswa Prodi Pendidikan Akuntansi FKIP UNBAJA

Berdasarkan kesimpulan di atas maka peneliti memberikan saran sebagai berikut:

1. Hendaknya kompetensi dasar dosen prodi Pendidikan Akuntansi FKIP UNBAJA dapat dipertahankan seperti kondisi sekarang ini dan sangat diharapkan jika kualitas kompetensi dasar dosen dapat ditingkatkan sehingga dapat menciptakan motivasi belajar mahasiswa yang lebih tinggi lagi.

2. Hendaknya segala fasilitas sarana dan prasarana yang dianggap oleh para mahasiswa masih belum cukup memadai untuk lebih ditindak lanjuti, supaya harapan mahasiswa dapat sebanding dengan kompetensi dasar dosen. 
3. Mahasiswa berperan sebagai peserta didik, sebaiknya lebih giat lagi dalam belajar

4. penelitian selanjutnya dapat disempurnakan mengenai kompetensi dasar dosen terhadap motivasi belajar mahasiswa dengan mengambil sampel seluruh mahasiswa Universitas Banten Jaya.

\section{DAFTAR PUSTAKA}

Arifin, Zaenal (2016). Evaluasi Pembelajaran. Bandung: PT Remaja Rosdakarya

Ferdinand, Agusty. (2014). Metode Penelitian Manajemen : Pedoman Penelitian untuk Skripsi, Tesis dan Desertasi Ilmu Manajemen. Semarang. Badan Penerbit Universitas Diponegoro.

Firdayanti, Restika. (2012). Journal of Social and Industrial Psychology. Persepsi Risiko Melakukan E-Commerce dengan Kepercayaan Konsumen dalam Membeli Produk Fashion Online [online], halaman 3. Tersedia: https://journal.unnes.ac.id/sju/index .php/sip/article/view/2660.

[Januari-Maret 2012]

Maonde, Faad (2011). Karya Ilmiah. Aplikasi Penelitian Eksperimen Dalam Bidang Pendidikan dan Sosial. Kendari: Unit Penerbitan dan Percetakan Universitas Haluoleo.
Mulyasa, E. (2010). Kurikulum Berbasis Kompetensi. Bandung: PT Remaja Rosdakarya.

Pramudyo, Anung (2010). Jurnal Bisnis Teori \& Implementasi. Analisis Faktor-Faktoryang Mempengaruhi Kinerja Dosen Negeri pada Kopertis Wilayah V Yogyakarta. [online]. halaman 3. Tersedia: journal.umy.ac.id

Pupuh Faturrohman dan M. Sobry Sutikno. (2014). Strategi Belajar Mengajar. Bandung:PT Refika Aditama

Sardiman, A.M. (2008). Interaksi dan Motivasi Belajar Mengajar. Jakarta: Rajawali Press.

Sudaryono. (2011). Statistik Deskriptif. Banten: Dinas Pendidikan Provinsi Banten

Sudaryono. (2016). Metode Penelitian Pendidikan. Jakarta: Prenadamedia Group

Sugiyono, (2015). Metode Penelitian Pendekatan Kuantitatif Kualitatif, dan $R \& D$. Bandung, Alfabeta.

Tahrir. (2013). Jurnal Ilmiah Psikologi. Pengaruh Kompetensi Dosen TerhadapMotivasi BelajarPada Mahasiswa Fakultas Psikologi UIN “SGD” Bandung[online], Vol. 6, No 1 halaman 757. Tersedia:http://journal.uinsgd.ac.id/ index.php/psy/article/view/2133/14 $\underline{67}$

Uno, Hamzah B (2012). Perencanaan Pembelajaran. Jakarta: PT Bumi Aksara. 